\title{
Relationship of habitat and spatial scale with physiological state and settlement of blue crab postlarvae in Chesapeake Bay
}

\author{
Karen S. Metcalf, Romuald N. Lipcius \\ Virginia Institute of Marine Science, The College of William and Mary, Gloucester Point, Virginia 23062, USA
}

\begin{abstract}
Physiological state (molt stage) of planktonic and benthic blue crab (Callinectes sapidus) postlarvae (megalopae) was quantified within and outside Chesapeake Bay at various spatial scales. Physiological state of planktonic megalopae advanced significantly from the continental shelf off the Chesapeake Bay mouth, through the bay mainstem, and into upriver stations in the York River, a tributary of Chesapeake Bay. These results imply that settlement and metamorphosis of blue crab megalopae is dependent on location relative to the shelf. The physiological evidence supports the export-reinvasion theory of blue crab recruitment and is inconsistent with a larval retention hypothesis. In the tributary, benthic megalopae were significantly more advanced in molt stage state than planktonic megalopae. Temporal variation in molt stage was observed over days and months. In addition, time to metamorphosis was significantly and positively correlated with molt stage. Advancement in physiological state of megalopae during reinvasion of the estuary may serve as an indicator of likelihood of settlement.
\end{abstract}

\section{INTRODUCTION}

Female blue crabs Callinectes sapidus Rathbun release larvae at the mouth of Chesapeake Bay, USA, in early summer through fall (Van Engel 1958, Provenzano et al. 1983). In continental shelf waters, larvae develop through 7 or 8 zoeal stages (Costlow 1967, McConaugha et al. 1983, Epifanio et al. 1989), before metamorphosis into the postlarval stage, or megalopa. The megalopal stage lasts from 6 to $58 \mathrm{~d}$ (Costlow \& Bookhout 1959, Costlow 1967, Sulkin \& Van Heukelem 1986), and is followed by metamorphosis into the first juvenile instar, initiating a benthic existence.

In attempts to elucidate recruitment mechanisms of the blue crab, various authors have examined the distribution of larvae and postlarvae relative to estuarine nurseries and spawning areas. Early zoeal stages are common at the mouths of estuaries, while later zoeal stages are generally only collected offshore (Epifanio et al. 1984, Johnson 1985). Megalopae have been collected offshore, as well as within Chesapeake Bay (Sandifer 1973). Thus, current theory holds that blue crab larvae are released at the estuary mouth, transported offshore, and subsequently reinvade the estuary as postlarvae. Alternatively, previous hypotheses suggested that blue crab larvae and megalopae were retained within the parent estuary. Details of estuarine reinvasion by blue crab megalopae are unclear. In particular, the relationships between physiological state, habitat features, and settlement are little understood, except at relatively small spatial scales (Lipcius et al. 1990).

Past studies have stressed the spatial distribution of crab megalopae relative to physiological state (Hatfield 1983) or temporal changes in developmental state of blue crab megalopae (Lipcius et al. 1990), but none have examined variation in postlarval physiological state relative to the combination of space, time, and habitat type at different spatial scales. In this study we examine the physiological state of blue crab megalopae in relation to geographic location [over large (tens of $\mathrm{km}$ ) and small ( $\mathrm{km}$ ) spatial scales], habitat, and time. We provide physiological evidence in support of the export and reinvasion theory for megalopal 
recruitment into Chesapeake Bay, and in support of the hypothesis that settlement propensity of megalopae is related to their physiological state, which varies over broad spatial scales in Chesapeake Bay.

\section{METHODS}

Molt staging and time to metamorphosis. Molt staging has been used successfully to assess physiological state in crustaceans since the study by Drach (1939). This technique allows inspection of microscopic changes in the integument of numerous crustacean body parts, such as pleopods (Aiken 1973), rostra (Anger 1983), scaphognathites (Van Herp \& BellonHumbert 1978), and maxillipeds (Hatfield 1983). By examining the extent of retraction of the epidermis from the cuticle, molt stages are readily and objectively identified for analyzing physiological state of recruiting postlarvae. We quantified molt stage in planktonic megalopae by examining, under a compound microscope $(45 \times)$, setal development and extent of epidermal retraction from the cuticle in the uropods and third maxillipeds. Molt stages were based on Aiken's (1973) morphological criteria (Table 1). Molt stages are nominal variables which represent a specific range of the continuous molting process.

Megalopae were collected in $1 \mathrm{~m}$ diameter, $750 \mu \mathrm{m}$ mesh neuston nets deployed from a pier in the York River during nocturnal flood tide (Stn R2; Fig. 1). Molt stage frequencies observed in the uropods were contrasted, using a paired $t$-test ( $n=471$ megalopae), with their corresponding stages observed in the maxillipeds to examine differences in times of development of different morphological areas. The Pearson productmoment correlation coefficient was calculated to assess the linear relationship between uropod and maxilliped molt stages.

Megalopae were collected, in the same manner, from the same location on 27 July 1989. They were immediately molt staged (1\% mortality from staging until metamorphosis), then held separately in aerated bowls containing York River water at $17 \pm 1$ ppt and $21 \pm 2{ }^{\circ} \mathrm{C}$. Every $3 \mathrm{~h}$, each of 24 megalopae was checked for metamorphosis. Time elapsed until metamorphosis into the first juvenile instar was recorded, and then regressed on initial uropod molt stage using simple linear regression.

Molt stage along the axis of the York River and Chesapeake Bay. We examined the molt stages of megalopae from 2 transects, one from the continental shelf off the mouth of Chesapeake Bay into the York River and one along the axis of flow within the York River, to quantify variation in physiological state over a geographic range (Fig. 1). Duplicate samples of 10 megalopae each were collected for the bay transect on 5 September and 5 October 1990 at each of 4 locations during nocturnal flood tide. Stations sampled were: offshore, east of the bay mouth (Stn B1, $22 \mathrm{~km}$ outside the bay mouth); near the bay mouth ( $S t n$ B2, within $1 \mathrm{~km}$ of the bay mouth); in the bay mainstem (Stn B3, $26 \mathrm{~km}$ inside the bay mouth); and in the York River (Stn B4, $50 \mathrm{~km}$ from the bay mouth). Samples for the river transect were collected during nocturnal flood tide on 18 October 1989. Two replicate samples of at least 10 megalopae each were

Table 1. Description of uropod and maxilliped characteristics visible under $45 \times$ magnification. After Aiken (1973)

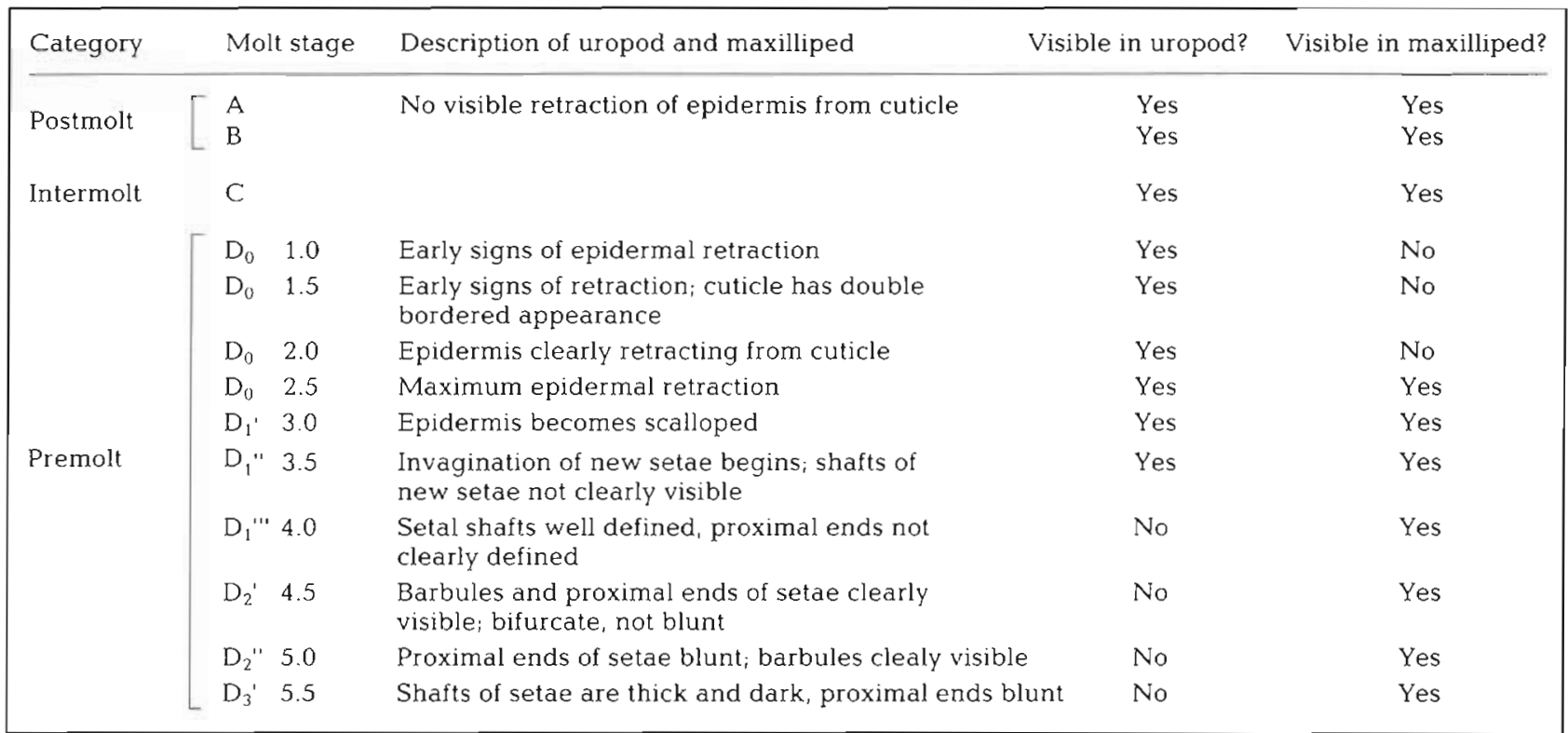




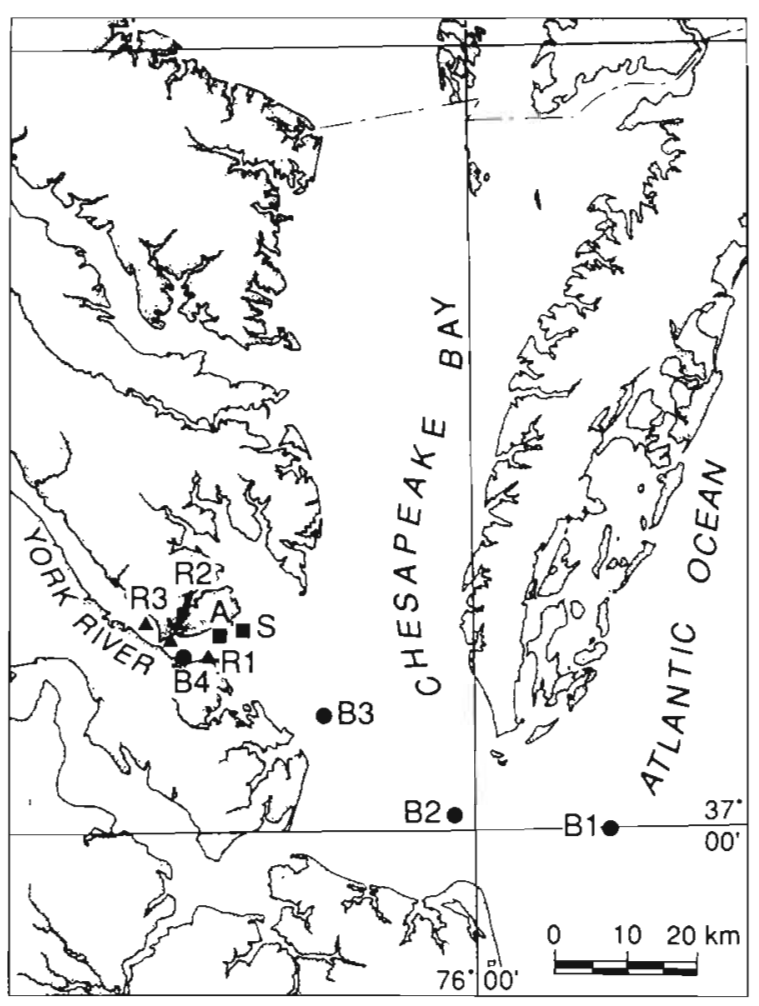

Fig. 1. Sampling locations for experiments. Stns B1 to B4 were bay transect, Stns R1 to R3 were river transect. Stns S and R2 were used for habitat, spatial, and temporal variation experiment. Stn A was used in Lipcius et al. (1990)

taken at 3 locations: $5.9 \mathrm{~km}$ upstream from the river mouth (Stn R1), $12 \mathrm{~km}$ upstream (Stn R2), and $18.7 \mathrm{~km}$ upstream (Stn R3). Each sample provided a single, independent datum as a proportion in premolt stages for subsequent statistical analysis. All megalopae were collected in a pair of $1 \mathrm{~m}$ diameter, $750 \mu \mathrm{m}$ mesh neuston nets. Molt stage was quantified in the uropods and maxillipeds within $2 \mathrm{~h}$ of collection, as described previously. For the baywide data in 1990. proportion of megalopae classified as premolt (stages $D_{0}$ to $D_{3}{ }^{\prime}$ ) was correlated with distance from the shelf using simple linear regression. Analysis of each separate stage was inappropriate because of the relatively small proportion of megalopae in premolt stages at the offshore and bay mouth stations. Distance from the shelf was chosen as the independent variable because it is a simple representation of all the factors which vary along this same gradient. Analysis of variance was performed on premolt stage by the factors location and month at the stations where premolt megalopae occurred in large numbers (>50\% of sample: Stns B3 and B4). In addition, molt stage was correlated with distance upriver for the 1989 river transect data.
Spatial and temporal variation in molt stage with habitat type. We examined the molt stages of megalopae during 2 recruitment episodes (16 to 21 September and 15 to 20 October 1989) in 2 habitat types (plankton and benthos), and at 2 locations (upriver and downriver) to quantify spatial and temporal variation in molt stage of megalopae within the York River. The downriver station, Sandy Point (Stn S, Fig. 1), was located $1.4 \mathrm{~km}$ from the mouth of the York River and was characterized by shallow beds of eelgrass Zostera marina and widgeongrass Ruppia maritima. The second location (Stn R2; Fig. 1) was $10.6 \mathrm{~km}$ upriver from Sandy Point and also was characterized by shallow eelgrass beds. These seagrass beds serve as a settlement habitat for blue crab megalopae (Orth \& van Montfrans 1990).

We took 2 replicate samples of 10 megalopae each from the plankton and benthos at each of the 2 sites. Plankton samples were collected with paired neuston nets (750 $\mu \mathrm{m}$ mesh) during nocturnal flood tide. Benthic samples were collected using a suction sampling device swept along the bottom in seagrass beds on the morning following the corresponding plankton sample (Orth \& van Montfrans 1987, Olmi et al. 1990).

Megalopae were molt staged (using uropods) within $1 \mathrm{~h}$ of collection to preclude advancement through the molt cycle. Megalopae in October samples were molt staged using maxillipeds, in addition to uropods. Loglikelihood analysis of molt stage frequencies (Sokal \& Rohlf 1981) was used, instead of ANOVA, because of incomplete replication of habitat types at the downriver location. Individual megalopae were widely dispersed and only together in the sampling apparatus for a short time; thus the molt stage of each megalopa was assumed to be an independent sample. A 4-factor, log-likelihood analysis was conducted on uropod molt stage frequencies for both months, with the factors: habitat, location, day, and month. A 3-factor loglikelihood analysis was conducted on maxilliped molt stage frequencies with the factors: habitat, location, and day.

\section{RESULTS}

\section{Molt staging and time to metamorphosis}

Time to metamorphosis was significantly and negatively correlated with uropod molt stage (Fig. 2; $\left.Y=51.7-19.0 X, \mathrm{r}^{2}=0.73, \mathrm{p}<0.01\right)$. Megalopae in early premolt took 21 to $47 \mathrm{~h}$ to metamorphose, while those in the most advanced stages metamorphosed in 3 to $6 \mathrm{~h}$. Hence, time to metamorphosis is inversely related to physiological state, even over the relatively narrow range of molt stages examined here. 


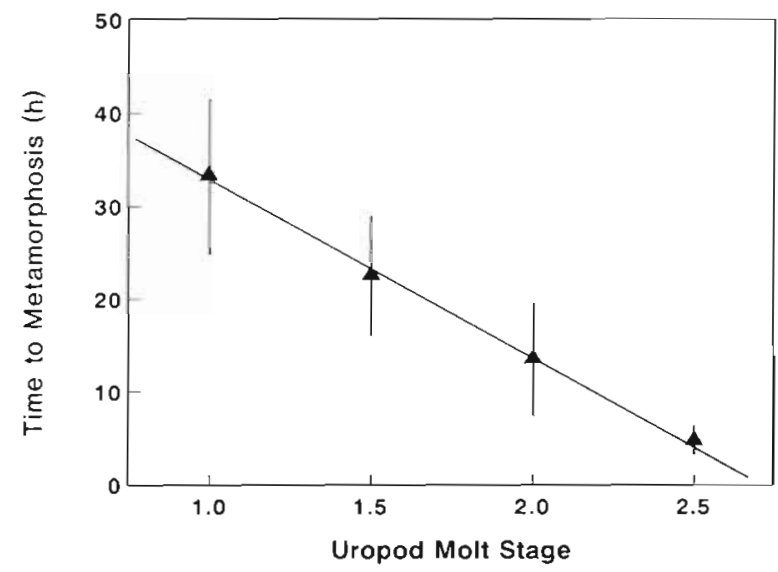

Fig. 2. Callinectes sapidus. Relationship of time to metamorphosis ( $\pm 1 \mathrm{SD}$ ) and developmental state of megalopae for uropod premolt stages

Maxillipeds were significantly more advanced in molt stage than uropods (Fig. 3; paired $t$-test, $t=52.7$. $\mathrm{df}=470, \mathrm{p}<0.01)$. The range in uropod molt stages was between $D_{0} 1.0$ and $D_{1}{ }^{11} 3.5$, while maxilliped molt stages ranged from $D_{0} 1.0$ to $D_{3}^{\prime} 5.5$. Maxilliped and uropod molt stages were positively correlated $(\mathrm{r}=0.622, \mathrm{df}=470, \mathrm{p}<0.001)$. Both morphological areas are examined in the experiments that follow because this allows identification of the full range of molt stages.

\section{Molt stage along the axis of the York River and Chesapeake Bay}

The proportion of megalopae in premolt along the Chesapeake Bay transect was significantly and posi-



Fig. 3. Callinectes sapidus. Comparison of uropod and maxilliped molt stages for premolt blue crab megalopae

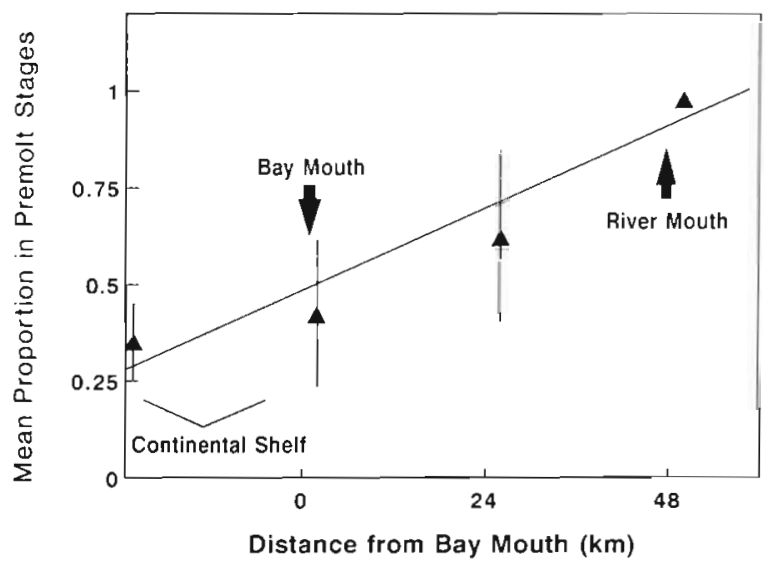

Fig. 4. Callinectes sapidus. Mean proportion of megalopae $(-1 \mathrm{SD})$ collected in premolt ( $D_{0}$ and beyond) versus distance from Chesapeake Bay mouth for shelf-bay transect. All megalopae collected at the station at $50 \mathrm{~km}$ were premolt $(\mathrm{SD}=0, \mathrm{n}=40$ )

tively correlated with distance from the shelf (Fig. 4; $Y=0.278+0.00896 X, r^{2}=0.67, p<0.01$ ). Megalopae within the estuary were significantly more advanced in physiological state than those near the bay mouth and offshore, though a substantial proportion (30\%) on the continental shelf was also in premolt (Fig. 4). Molt stage proportions differed by station and month for the stations with the most developmentally advanced megalopae (bay mainstem and York River). There were proportionally fewer megalopae in advanced molt stages during September than during October (ANOVA, $F=6.84$, df $=1,64, p=0.01$ ). Megalopae from the station in the bay mainstem were significantly less advanced $(58 \%$ intermolt, $42 \% \mathrm{D}_{0}$ ) than those collected at the York River

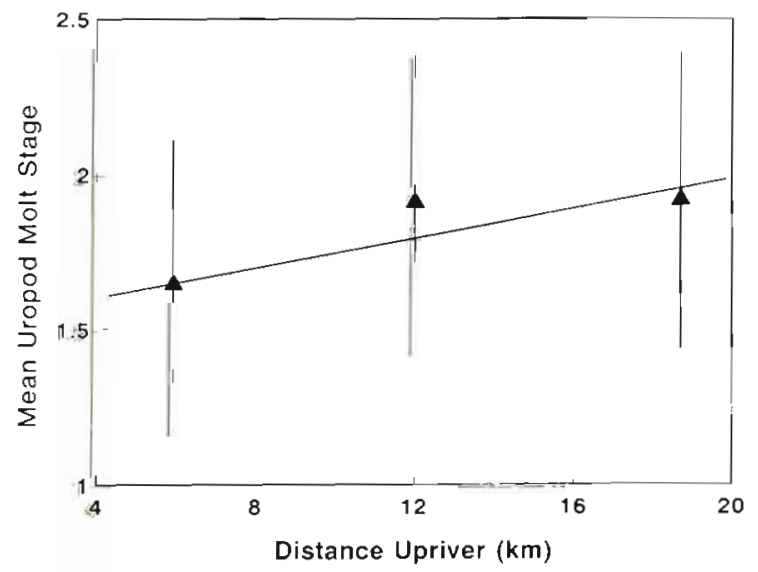

Fig. 5. Callinectes sapidus. Mean molt stage । 1 SD) versus distance upriver for megalopae collected during a transect of the York River 
station $\left(40 \% \quad D_{0}, \quad 25 \% \quad D_{1}, \quad 28 \% \quad D_{2}, \quad 7 \% \quad D_{3}\right)$ (ANOVA, $F=11.06, \mathrm{df}=1,64, \mathrm{p}<0.01$ ). Physiological state was significantly and positively correlated with distance upriver within the York River $\left(Y=1.53+0.0233 X, \mathrm{r}^{2}=0.06, \mathrm{p}=0.04\right)$. Those megalopae collected upriver were more advanced than those near the river mouth (Fig. 5), though the absolute difference was very small relative to that in the bay transect.

\section{Spatial and temporal variation in molt stage with habitat type: uropod}

The effect of collection day on uropod molt stage was not significant in any cases ( $G$-test, $G=3.37$, df $=2, p=0.19$ ) during the study of effects of habitat, location and day on molt stage. In both the plankton and benthos, molt stage frequencies were significantly more advanced in October than September (Fig. 6; G-test; plankton, $G=21.01$, df $=2, p<0.01$; benthos, $G=27.69, \mathrm{df}=2, \mathrm{p}<0.01$ ). This pattern is similar to that observed in the bay transect. The effect of geographic location on uropod molt stage frequency was only significant in benthic samples collected in October, such that upriver samples were more advanced than downriver samples (Fig. 6; $G$-test, $G=4.24$, df $=2, p=0.01 \mathrm{j}$. Megalopae collected in September showed no significant effect of geographic location (Fig. 6; G-test, $G=1.11$, df $=2$, $\mathrm{p}=0.57$ ). Molt stages from planktonic megalopae did not differ significantly with location in October
(Fig. 6; G-test, $G=2.56, \mathrm{df}=2, \mathrm{p}=0.28$ )

The effect of habitat on the frequency of megalopae in each molt stage varied with location. Megalopae collected from the plankton at the upriver station were significantly less advanced than those from the benthos at that site, although the degree of significance varied with month sampled (Fig. 6; G-test; September, $G=6.62, \mathrm{df}=2, \mathrm{p}=0.04$; October, $G=$ 29.59, df $=2, p<0.01$ ). Habitat differences at the downriver station were not significant in September (Fig. 6; $G$-test, $G=6.42, \mathrm{df}=2, \mathrm{p}=0.06$ ) or October $(G$-test, $G=2.54$, df $=2, p=0.27)$.

\section{Spatial and temporal variation in molt stage with habitat type: maxilliped}

Megalopae showed a significant increasing trend in maxilliped molt stage over the $5 \mathrm{~d}$ period in October 1989 ( $G$-test, $G=10.89$, df $=2, \mathrm{p}<0.01$ ). As with the uropod molt stages, maxilliped molt stages were significantly more advanced in the benthos than in the plankton at the upriver location (Fig. 7; G-test, $G=24.17, \mathrm{df}=2, \mathrm{p}<0.01)$. Megalopae collected near the river mouth did not show a significant effect of habitat type ( $G$-test, $G=0.96, \mathrm{df}=2, \mathrm{p}=0.62$ ). Benthic megalopae from the upriver station were significantly more advanced in maxilliped molt stage than those from the downriver station (Fig. 7; G-test, $G=11.63 . \mathrm{df}=2, p<0.01)$. Megalopae in the plankton showed no trend with location ( $G$-test, $G=1.83$, $\mathrm{df}=2, \mathrm{p}=0.40$ ).
Fig. 6. Callinectes sapidus. Proportion of uropod molt stages for megalopae collected from plankton and benthos for each station and month. (a) September downriver, (b) September upriver, (c) October downriver, (d) October upriver a. Downriver September

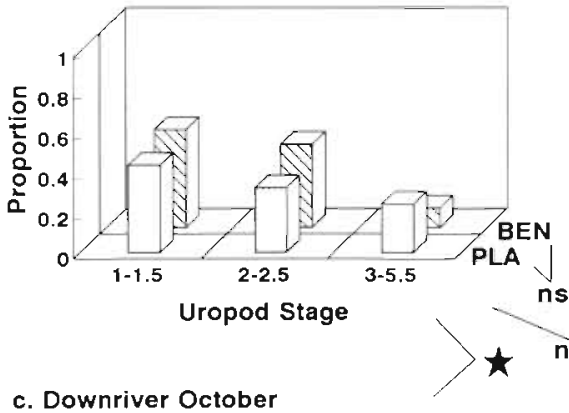

c. Downriver October

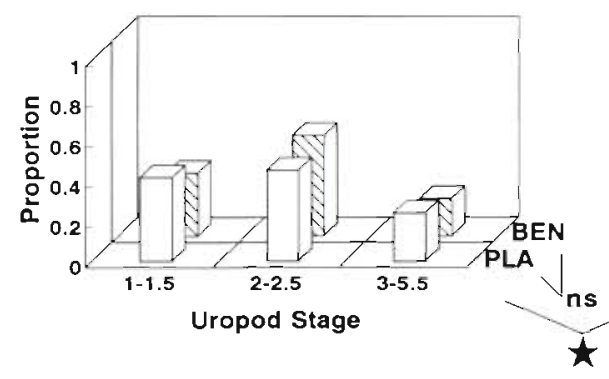

b. Upriver September

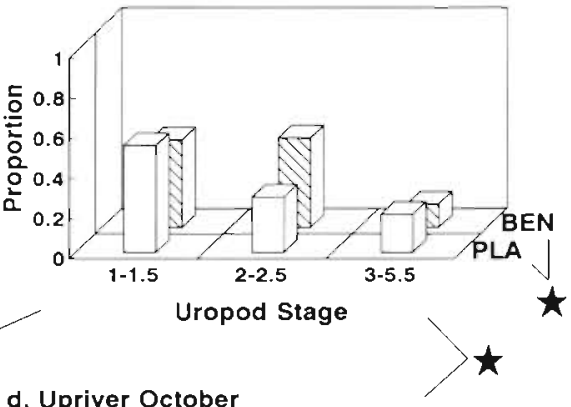

d. Upriver October

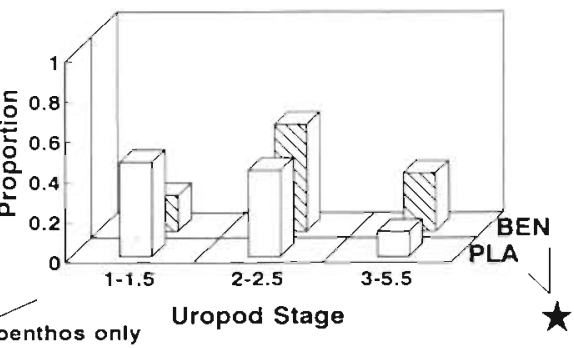


a. Downriver - October

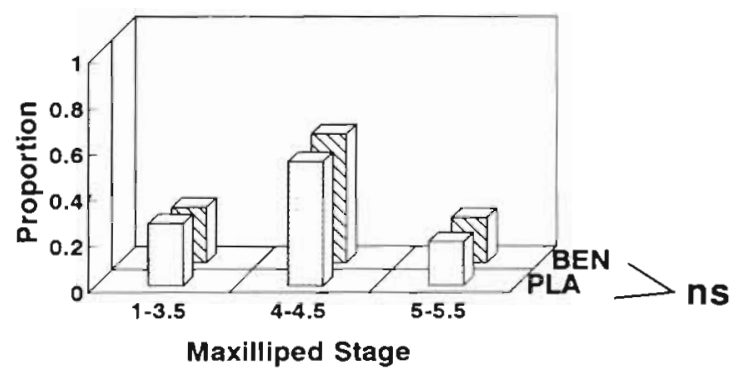

$>\star$ (benthos only)

\section{b. Upriver - October}

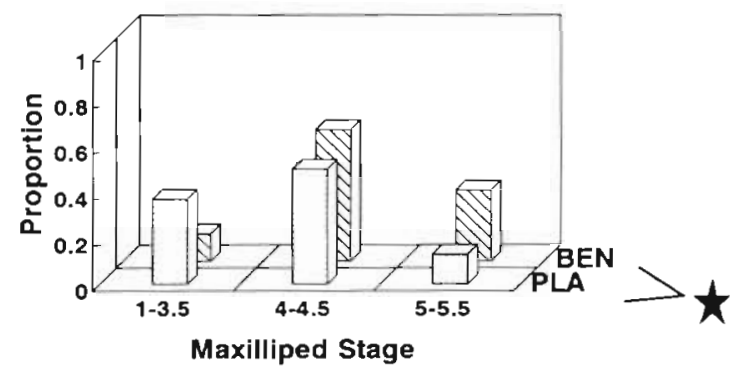

Fig. 7. Proportion of megalopae ranked by maxilliped stages in plankton and benthos for each station. (a) Downriver, (b) upriver

\section{DISCUSSION}

Blue crab megalopae advance in physiological state from the continental shelf into Chesapeake Bay and one of its tributaries (York River). Physiological state of megalopae within the tributary advances from the plankton to the benthos and to a lesser degree with distance from the mouth of the York River. This progression on a baywide scale is consistent with a recruitment model postulating that blue crab megalopae reinvade Chesapeake Bay after being exported onto the continental shelf as larvae (Sulkin \& Van Heukelem 1982), and inconsistent with the hypothesis that blue crab larvae and megalopae are retained in Chesapeake Bay (Van Engel 1958). The inconsistency lies in the orderly progression in developmental state from the shelf to the York River; the retention hypothesis would predict a progression from the lower bay out to the shelf (larvae and megalopae lost from the bay system) and a similar progression from the lower bay to its tributaries (retained larvae and megalopae). The physiological evidence from this study supports the export and reinvasion hypothesis for blue crab larvae and megalopae.
We encountered variation in physiological state over a period of days. Maxilliped molt stages advanced in physiological state over a $5 \mathrm{~d}$ period. This trend may not have been significant in the uropod molt stages because the later premolt stages are not well represented in this morphological area (Table 1). Abundance of megalopae in the plankton in the York River is episodic with high abundance associated with the new and full moon during summer and fall (Olmi et al. 1990). A group of megalopae may pulse into the estuary at one of these times, advancing in physiological state as they progress upriver. Previous authors encountered a similar trend in physiological state over a period of days (Lipcius et al. 1990).

Physiological state of megalopae differed significantly between planktonic and benthic megalopae, with those in the plankton less advanced than those in the benthos. The habitat differences were most pronounced at upriver stations. This suggests either that postlarvae which are more advanced in physiological state settle sooner than those which are less advanced, or that settled postlarvae continue through the molt cycle more rapidly and are thus in more advanced molt stages. Since many planktonic megalopae were in late premolt stages, it is likely that megalopae must settle once they have reached a significantly more advanced 'threshold' molt stage. Behavioral observations are required to determine if blue crab megalopae settle because of impending metamorphosis, or if they metamorphose because they have settled. In either case, the progression of molt stages is directly related to the behavioral events occurring near settlement.

Variation in physiological state over time scales of months may be the result of variation in the physical factors influencing larval development and transport. Location on the shelf at which a megalopa first appears (and its consequent physiological state at a particular location, assuming it cannot regulate physiological state) will be a function of the time of hatching, the duration of zoeal development, and the characteristics of the currents in which the zoeae have been entrained (Sulkin \& Van Heukelem 1986). Simulations of blue crab larval transport suggest that variable wind speeds and river flows cause blue crab larvae to travel at very different rates, resulting in variable reinvasion within and between years (Johnson \& Hess 1990). In addition, the rate of development of larvae and postlarvae is affected by variations in salinity and temperature (Costlow \& Bookhout 1959, Costiow 1967). Thus, ontogenetic changes in vertical distribution during larval development can influence dispersal not only by subjecting larvae to different circulation fields, but also by influencing larval development rate (Sulkin \& Van Heukelem 1986). Small-scale patchiness, current patterns, and megalopal behavior have all been 
implicated in the geographic distribution of developmental states in planktonic Dungeness crab megalopae (Hatfield 1983).

Our data from the 1990 Chesapeake Bay transects qualitatively predicted molt stages in the York River comparable to those found in 1987 to 1989 sampling (Lipcius et al. 1990 and the current study), and those expected by the export-reinvasion hypothesis. Molt stages of megalopae within the York River advanced slightly with distance upriver. Quantitatively, the regression model for the bay transect (present study) predicted that $85 \%$ of the megalopae collected on the full moon in the plankton would be in premolt at the York River mouth. For 1987 data (Lipcius et al. 1990), the proportion in premolt $(60 \%)$ was slightly lower (at Stn $A_{i}$ Fig. 1). Our 1989 data had a proportion in premolt $(100 \%)$ at the river mouth higher than that predicted based on the bay transect data. The upriver station (Stn R2) from the 1987 and 1989 data more closely conforms to the prediction of $97 \%$ for that location. There, in 1987,81 to $100 \%$ of the collected megalopae were in premolt stages. In 1989, $100 \%$ of those collected were in premolt in the York River. The variation in the proportion of megalopae in premolt stages relative to the predicted values may be due to temporal

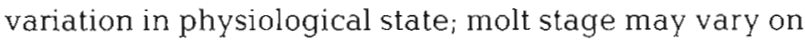
the order of days and months. Quantitatively, the molt stages predicted by these data are not exactly the same as those from past studies, but qualitatively, the trends are equivalent.

The usefulness of molt stage for predicting settlement within the York River may be limited due to the low variability of molt stages in that portion of the system. Megalopae which have been transported beyond the river mouth are generally all in premolt stages $\left(D_{0}\right.$ and beyond) and thus show little difference in stage over this relatively small range. On a baywide scale, developmental state may be a valid predictor of settlement, because those megalopae nearing settlement to the benthos are of the most advanced molt stages.

The molt staging technique used as a quantitative measure was an accurate and reliable indicator of proximity to metamorphosis. Staging of both the uropods and maxillipeds produced similar results with respect to relative variation in the factors studied. The condition of the uropods is a better indicator of less advanced molt stages, while the condition of the maxillipeds most clearly identifies more advanced molt stages. Combining observations of both uropods and maxillipeds would be most useful.

Our results agreed with those of Lipcius et al. (1990), who found variation in developmental state of megalopae on smaller spatial and temporal scales. This study further advances the idea that changes in physiological state coincide with the timing of megalopal reinvasion and settlement. Variability in recruitment of the blue crab may be influenced by events occurring at or near the time of settlement and metamorphosis from the larval (or postlarval) to the juvenile form. Understanding that the factors we studied are correlated with physiological state may aid in predicting conditions for settlement and eventual recruitment into the adult population.

Acknowledgements. We thank A. Hines, D. Knott, S. Morgan, E. Olmi, R. Orth, J. van Montfrans, and 3 anonymous reviewers for reviews and A. Curry, P. Gerdes, B. Layman, S. Mauger, J. Mintz, P. Oliver and E. Olmi for technical assistance. This work was supported by funds from the Commonwealth of Virginia, Virginia Sea Grant (NA86AA-DSG042 and NA90AA-D-SG045) and a generous donation from Lewis L. Glucksman. Contribution No. 1743 of the Virginia Institute of Marine Science.

\section{LITERATURE CITED}

Aiken, D. E. (1973). Proecdysis, setal development, and molt prediction in the American lobster (Homarus americanus). J. Fish. Res. Bd Can. 30:1337-1344

Anger, K. (1983). Moult cycle and morphogenesis in Hyas araneus larvae (Decapoda, Majidae), reared in the laboratory. Helgoländer Meeresunters. 36: 285-302

Costlow, J. D., Jr (1967). The effect of salinity and temperature on survival and metamorphosis of megalops of the blue crab Callinectes sapidus. Helgoländer wiss. Meeresunters. 15: 84-97

Costlow, J. D. Jr, Bookhout, C. G. (1959). The larval development of Callinectes sapidus Rathbun in the laboratory. Biol. Bull. mar. biol. Lab., Woods Hole 116: 373-396

Drach, P. (1939). Mue et cycle d'intermue chez les crustacées decapodes. Ann. Inst. Ocèanogr. Monaco 19: 103-391

Epifanio, C. E., Valenti، C. C., Pembroke, A. E. (1984). Dispersal and recruitment of blue crab larvae in Delaware Bay, USA. Estuar. coast. Shelf Sci. 18: 1-12

Epifanio, C. E., Masse, A. K., Garvine, R. W. (1989). Transport of blue crab larvae by surface currents off Delaware Bay, USA. Mar. Ecol. Prog. Ser. 54: 35-41

Hatfield, S. E. (1983). Intermolt staging and distribution of Dungeness crab, Cancer magister, megalopae. Calif. Dep. Fish Game Fish. Bull, 172: 85-96

Johnson, D. F. (1985). The distribution of brachyuran crustacean megalopae in the waters of the York River, Lower Chesapeake Bay and adjacent shelf: implications for recruitment. Estuar. coast. Shelf Sci. 20:693-705

Johnson, D. F. Hess, K. W. (1990). Numerical simulations of blue crab larval dispersal and recruitment. Bull. mar. Sci. 46: $195-213$

Lipcius, R. N., Olmi, E. J. III, van Montfrans, J. (1990). Planktonic availability, molt stage and settlement of blue crab postlarvae. Mar. Ecol. Prog. Ser. 58: 235-242

McConaugha, J. R., Johnson, D. F., Provenzano, A. J., Maris, R. C. (1983). Seasonal distribution of larvae of Callinectes sapidus (Crustaceana: Decapoda) in the waters adjacent to Chesapeake Bay. J. Crust. Biol. 3: 582-591

Olmi, E. J. III, van Montfrans, J., Lipcius, R. N., Orth, R. J., Sadler, P. (1990). Variation in planktonic availability and 
settlement of blue crab megalopae in the York River, Virginia. Bull. mar. Sci. 46: 230-243

Orth, R. J., van Montfrans, J. (1987). Utilization of a seagrass meadow and a tidal marsh creek by blue crabs Callinectes sapidus. I. Seasonal and annual variations in abundance with emphasis on post-settlement juveniles. Mar Ecol. Prog. Ser. 41: 283-294

Orth, R. J., van Montfrans, J. (1990). Utilization of marsh and seagrass habitats by early stages of Callinectes sapidus: a latitudinal perspective. Bull. mar. Sci. 46: 126-144

Provenzano, A. J., Jr, McConaugha, J. R., Philips, K. B., Johnson, D. F., Clark, J. (1983). Vertical distribution of first stage larvae of the blue crab. Callinectes sapidus, at the mouth of Chesapeake Bay. Estuar. coast. Shelf Sci. 16: 489-499

Sandifer, P. A. (1973). Distribution and abundance of decapod crustacean larvae in the York River estuary and adjacent Lower Chesapeake Bay, Virginia, 1968-1969. Chesapeake Sci. 14: 235-257

This article was presented by K. L. Heck, Dauphin Island, Alabama, USA
Sokal, R. R., Rohlf, F. J. (1981). Biometry. W. H. Freeman, New York

Sulkin, S. D., Van Heukelem, W. F. (1982). Larval recruitment in the crab Callinectes sapidus Rathbun: an amendment to the concept of larval retention in estuaries. In: Kennedy, V. S. (ed.) Estuarine comparisons. Academic Press, New York, p. 459-475

Sulkin, S. D., Van Heukelem, W. F. (1986). Variability in the length of the megalopal stage and its consequence to dispersal and recruitment in the portunid crab Callinectes sapidus Rathbun. Bull. mar. Sci. 39: 269-278

Van Engel, W. A. (1958). The blue crab and its fishery in Chesapeake Bay. Part i - Reproduction, early development, growth and migration. Comml Fish. Rev. 20: $6-17$

Van Herp, F., Bellon-Humbert, C. (1978). Setal development and molt prediction in the larvae and adults of the crayfish, Astacus leptodactylus (Nordmann, 1842). Aquaculture 14: 289-301

Manuscript first received: June 21, 1991

Revised version accepted: March 2, 1992 